DOI: https://doi.org/10.31874/2309-1606-2020-26-2-1

УДК 261.7

\title{
Юрій Чорноморець
}

\section{Перспективи розвитку духовної освіти в Україні}

Стаття присвячена критичному дослідженню бачення українськими богословами можливих перспектив розвитку духовної освіти в Україні у зв'язку із очікуваними різними теологами

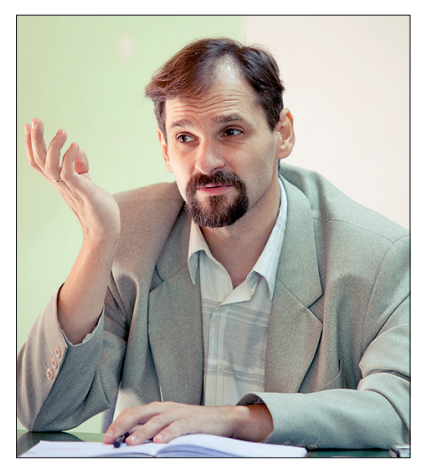
загальними змінами позиції релігії у національному публічному просторі, виявленню того, з чим у дійсності пов'язаний потенціал подальших позитивних змін в українській теології та духовній освіті. Украӥнські богослови та їх симпатики серед дослідників позитивні перспективи розвитку духовної освіти пов'язують із новими можливостями, які нібито надає світогляд постмодерну або пост-постмодерну. Сьогодення оцінюється як постсекулярний стан соціальності, оскільки релігія повертається у публічну сферу. У зв'язку з цим критикується характерний для модерну дуалізм світського і релігійного, модерне ототожнення соціального із світським і віднесення релігійного виключно до приватної сфери життя. Українські богослови та їх симпатики вважають, що самі по собі криза теорій секуляризації та повернення релігії у публічну сферу легітимізують існування богослов'я як науки та визнання духовної освіти як частини загальнонаціонального освітнього простору. Правове визнання богослов'я у 2014 році відкрило можливості для легітимізації богословських ідей у загальнонауковому дискурсі, але виявилося, що навіть політичне богослов'я та теологія освіти можуть запропонувати лише доволі обмежені проекти, що розвивають ідеї західного постмодерного неоавустіанства. Ситуація погіршується через панування у значній кількості семінарій та у великій кількості конкретних напрямків богослов'я «теології повторення», через неспроможність запропонувати власні християнсько-демократичні ідеї, через відмову від створення соціальне вчення, яке б відповідало складним викликам сьогодення. Здійснений аналіз доводить, що сьогодні сталий розвиток мають ті конфесійні системи духовної освіти Україні, які забезпечені лідерськими науково-дослідницькими інституціями. Ці інституції створюють наукову продукцію високої якості, задають загальний високий рівень викладання і навчання, здійснюють підготовку кадрів вищої кваліфікації. Таким чином, саме модерна освітня технологія створення певної конфесією (чи їх об'єднанням яку випадку протестантів) головного наукового і навчального центру, який діє за всіма національними і світовими стандартами освіти та науки, дозволяє лемітимізувати

(C) Ю. Чорноморець, 2021 
богослов'я та створити умови для розвитку всіх елементів конфесійних систем духовної освіти.

Ключові слова: богословська освіта, форми богословської освіти, зміст богословської освіти, соціальне покликання теології.

\section{Вступ}

Для пострадянського простору довгий час традиційним було розділення духовної та світської освіти [Хромець 2019: 81-126]. 3 початку XIX століття у Російській імперії підготовка священнослужителів була відділена від університетської освіти через побоювання впливу на богословів вільної наукової думки. За часів радянської влади відділення закладів вищої духовної освіти від світського освітнього простору набуло рис радикального дуалізму. Після здобуття Україною незалежності духовна освіта зберігала власну автономію, духовні навчальні заклади належали до числа релігійних організацій і керувалися виключно внутрішніми для церков правилами власного розвитку [Санников 2007; Bohn 1997; Charter 1997; Elliott 1999; Пеннер 1999]. При цьому результати навчання та наукової діяльності формально не визнавалися, що створювало ситуацію невиправданої дискримінації [Хромець 2019: 127-180]. Боротьба за визнання привела до включення у законодавство про освіту в 2014 році цілого ряду норм, які дозволяли духовним навчальним закладам проходити акредитацію та ліцензування, видавати документи державного зразка про освіту, через комісії МОН визнати здобуті раніше у духовних навчальних закладах дипломи про освіту, наукові ступені та вчені звання [Хромець 2019: 214-237]. За кілька років цілий ряд православних, протестантських, католицьких закладів вищої освіти скористалися з норм законодавства 2014 року. Разом із тим, намітилися деякі кризові явища у розвитку духовної освіти в Україні, пов'язані як з новими соціальними викликами, так із долею теології як академічної науки, що фактично включає у себе цілий ряд дисциплін, в межах яких релігійний та науковий світогляди знаходять власну єдність у цілком відмінні способи. Важливою стала тенденція мінімізації розвитку теології в університетському середовищі України, що стало наслідком надання духовним закладам освіти більших можливостей, зростанням вартості навчання у державних університетах, втратою у церков інтересу до розвитку богословських факультетів, кафедр і відділень в світських вищих навчальних закладах. Все більш очевидною стає потреба у комплексному осмисленні подальших перспектив розвитку богослов'я та духовної освіти в Україні, подальшого формування системи співіснування духовної та світської освіти у межах єдиного і власне світського за своїм загальним характером, освітнього простору України. 
Мета статті - дослідити бачення українськими богословами можливих перспектив розвитку духовної освіти в Україні у зв'язку із очікуваними різними теологами загальними змінами представлення релігії у національному публічному просторі та виявити з чим пов'язаний дійсний потенціал позитивних змін в українській теології та духовній освіті.

\section{Загальний стан конфесійної духовної освіти та наукових досліджень у галузі богослов’я в сучасній Україні}

Станом на 1 січня 1991 року в Україні існували 10 духовних навчальних закладів. Процеси стрімкого зростання релігійних організацій вимагали кадрового забезпечення і у подальшому було засновано ще 265 закладів вищої духовної освіти. Більше ста з цих закладів успішно розвиваються і сьогодні, хоча в основному кадровий голод в релігійних організаціях України вже подолано, і тому великої кількості студентів вже не спостерігаємо. Окремі церкви переживають кризу покликань до служіння і через це семінарії закриваються (яскравим прикладом тут можуть служити римо-католики України). Протестантська система освіти вже давно переорієнтувалася на підготовку не лише професійних пасторів, а й активних мирян. Сьогодні православні академії та семінарії теж активно шукають шляхи до оновлення системи освіти та надання професійної підготовки ширшої за традиційні служіння (священник, богослов, регент, іконописець). Бажання готувати викладачів християнської етики стикається з неможливістю надавати таку кваліфікацію, бо вона зарезервована чинними нормативними актами за педагогічними ВНЗ. Збереження високої кількості студентів вищих навчальних закладів сьогодні забезпечується за рахунок дотацій від релігійних організацій та зарубіжних спонсорів. Кілька десятків провідних духовних ВНЗ розпочали процеси здобуття державної акредитації, через що система духовної освіти переживає нові труднощі, пов'язані з необхідністю виконання вимог МОН і НАЗЯВО.

Першою проблемою $\epsilon$ кадрове забезпечення розвитку духовної освіти. Значна кількість професійних богословів підготовлена у межaх самих духовних закладів та на Заході. Разом із тим, в Україні гостро не вистачає докторів наук з богослов'я. На сьогодні греко-католики мають таких 3 докторів (Р. Завійський, М. Горяча, О. Каськів), православні - 6 (Г. Христокін, В. Рубський, І. Горохолінська, О. Трофимлюк, В. Клос, К. Лозінський, С. Думенко), протестанти - 4 (Р. Соловій, В. Санніков, М. Мокієнко, Ф. Стрижачук). Половина з цих докторів були визнанні комісією МОН, половина - захищені в НПУ імені М.П.Драгоманова. Зараз у названому університеті підготовлені до захисту ще 4 доктори - 2 православні (Д. Морозова, А. Кислий), 1 - мусульманин (Д. Брильов), 1 - греко- 
католик (Б. Завідняк). Визнаних і захищених кандидатів на сьогодні в Україні існує вже близько ста, і процеси захистів все ще продовжуються, бо семінарії, особливо - протестантські, направляють численних претендентів до аспірантури. Богословська спільнота з представників всіх конфесій, що дійсно займається наукою, здатна до проведення спільних конференцій, реалізації спільних проектів, добре інтегрована у західний науковий дискурс. Якщо говорити про світське наукове середовище, то найкращі зв'язки у богословів склалися із істориками та релігієзнавцями, діалог з представниками інших наук має лише деякі успішні проекти (реалізовані дослідження з історії філософії, аналітичної традиції, численні переклади тощо).

Розвиток наукових досліджень у галузі богослов'я має в Україні яскраво виражену конфесійну специфіку. Українські протестанти змогли створити власний великий Біблійний коментар, який охопив усі канонічні книги Біблії та має яскраво виражену контекстуалізацію для Східної Європи. Цей коментар писали в основному баптисти і п’ятидесятники, які глибоко вкорінені у місцевому контексті, але і мали західну богословську освіту. Коментар викликав значне зацікавлення на Заході. Українські протестанти видають професійні богословські журнали, серед яких особливо якісним стали «Богословські роздуми», що претендують на індексацію в Scopus. Викладачами українських протестантських ВНЗ створено значна кількість монографій та підручників, які написані на високому теоретичному рівні.

Українські греко-католики мають значні досягнення в області історичної науки, перекладів, створення підручників. В цілому наукові дискусії у греко-католицькому середовищі мають вторинний характер, оскільки молоді богослови повторюють тези трьох напрямків думки XXXXI століття: православного богослов'я, постмодерного богослов'я, католицького консервативного богослов'я. У дусі православного богослов'я не лише створені численні дослідницькі тексти, а й написано катехизм УГКЦ «Христос - Наша Пасха». Постмодерне богослов'я дозволяє розвивати біблеїстику та діалог з філософією. Консервативне католицьке богослов'я пропагандується в основному активістами руху захисту життя від природного зачаття до природної смерті особистості, і переживає очевидну кризу власного дискурсу. Численні виклики сьогодення спонукають УГКЦ до уважного використання соціальної доктрини католицизму, при чому собори єпископів та богослови постійно намагаються дати контекстуалізації різних аспектів цього вчення для України та діаспори.

Православні України мають значні досягнення в області патрології, історії, політичної теології, видають кілька журналів з науковими статтями, випустили ряд підручників. Більшість продукованих православними текстів з богослов'я мають ознаки «богослов'я повторення»: 
лише лідери богословської думки України не бояться бути новаторами в області богослов'я, звичайні ж науковці православного віросповідання не можуть або не хочуть ризикувати і допускати повністю самостійне творче мислення у власному середовищі. Такі явища приводять до кризи у православній духовній освіті, оскільки викладання загальновідомих богословських тез без внесення проблемного елементу та персонального творчого підходу в часи інтернет-відкритості часто просто втрачає сенс. Формування власних традицій новаторського викладання за взірцями православних богословських програм Греції чи США лише розпочинається. Якщо протестанти і греко-католики давно переклали основні підручники, енциклопедії та монографії, необхідні для ознайомлення студентів з найбільшими богословськими досягненнями кінця XX - початку XXI століть, то в українському православ'ї відповідна систематична робота так і не була здійснена. Відмітимо, що ще кілька років тому були значні надії на формування під впливом теології О. Шмемана власної богословської інноваційної традиції. Але сьогодні вже є очевидним, що українське наслідування євхаристійної теології Шмемана і Зізіуласа стало лише одним із елементів «теології повторення». Новий етап боротьби за українське православ'я показує, що представники багатьох помісних православних церков зачаровані не лише матеріальними вигодами від РПЦ, а й високим авторитетом російської духовної традиції. За цих умов нагальним постає завдання наявності принципових успіхів київського християнства у богослов'ї, екуменічному діалозі, релігійній філософії. Історичний досвід формування багатьох богословських та релігійно-філософських шкіл доводить, що необхідними складовими успіху та впливу є: наявність надійної спонсорської підтримки; формування національної спільноти богословів; участь богословів у основних інтелектуальних дискусіях цілого соціуму. Так було при формуванні російської релігійної філософії, паризької школи богослов'я, грецького православного богослов'я 1960х, сучасного американського православного богослов'я. Аналогічно творилася і києво-могилянська традиція. Сьогодні у світовому православ'ї триває ідейна боротьба між відкритим православ'ям та фундаменталізмом. ПЦУ свідомо підтримує модель відкритого православ'я, що перемогла в грецькому, американському та румунському православ'ях, має значний потенціал до історичного успіху у всіх інших церквах. Формування ідейно багатого національного відкритого православ'я можливе лише в умовах долученності до світових богословських дискусій. За цих умов критично важливим $є$ надання богословському середовищу та вірним ПЦУ нових перекладів американських та грецьких богословів. Свого часу переклад творів Йоана Зізіуласа змінив еклезіологічні уявлення українських богословів, а потім єпископату, оскільки інтуїції Лотоцького та інших ідеологів класичного 
українського автокефалізму отримали надійне підгрунтя. Аналогічно сьогодні переклад західних православних авторів кінця XX - початку XXI століть міг би значно змінити ідентичність українського богослов'я. Також важливим $є$ підвищення загального рівня культури богословів, священства і вірних завдяки систематичному перекладу основних праць сучасних православних богословів з проблематики систематичної теології, біблеїстики, патристики. Але головним є надання українському православ'ю інструментарію сучасної православної політичної теології, особливо - Фордемської школи, яка запропонувала православну теорію демократії та прав людини, надавши нову богословську основу для соціального вчення відкритого православ’я Вселенського патріархату.

\section{Перспективи розвитку релігії, теології та духовної освіти в українському суспільстві доби пост-постмодерну згідно з богословськими теоріями: критичний аналіз}

Основним засобом для легітимізації повноцінного розвитку духовної освіти в України стала апеляція до теорій постсекулярного стану [Соловій 2012; Пеннер 2015; Searle 2018; Пеннер 2019]. 31990 року на Заході розгорнулися широкі філософсько-релігієзнавчі та богословські дискусії щодо наслідків повернення релігії у публічну сферу, яке стало фактом з кінця 1970-х років. Надії на торжество секуляризації змінилися визнанням факту все більшої плюралізації у соціумі. Знаменитою теорію постсекулярного стану стала після аргументації Ю. Габермаса на користь надання релігійним організаціям права повноцінного голосу в суспільних дискусіях за умов виразу релігійних цінностей на універсальній світоглядній мові, яка фактично є мовою секулярного світогляду. Те, що фактично такі процеси відбуваються було доведено такими класиками сучасної соціології релігії як П. Бергер, Д. Белл, Х. Казанова. Якщо філософські та релігієзнавчі теорії звертають увагу на активізацію участі релігії у соціальному і політичному житті як ознаці «постсекулярного стану», то богослови наголошують на тому, що постсекулярний стан $€$ частиною постмодерної культури, яка долає модерний дуалізм між світським та релігійним, розумом і вірою, філософією і теологією. Хоча відповідні розрізнення були відомі античній та середньовічній культурі, цілий ряд сучасних богословів намагається представити домодерну культуру як тотально релігійну, а виділення світського простору як автономного та подальше його домінування описують як девіантний історичний процес, який мав штучний характер та привів до цілого ряду криз. Особливо знаменитими ці теорії стали у їх викладі в книзі засновника радикальної ортодоксії Дж. Мілбанка «Теологія і соціальна теорія» 
(1990), де теологія представлена як мета-наука, що може судити усі інші дискурси, а класичні соціальні теорії показані як «християнські єресі». Теорія про історичне виникнення у добу раннього модерну уявлень про світське як щось автономне і універсальне була підтримана філософом Ч. Тейлором і після цього набула певного поширення і набула нового впливу у теології. В українських реаліях представники релігійних спільнот вчення про автономність та універсальність світського та приватність релігійного також відносять до спадщини радянського світогляду, від усіх стереотипів якого необхідно обов'язково звільнитися. Метою цього звільнення має бути повне забезпечення прав і свобод особистості, захист світоглядної нейтральності. Теорії постсекулярного стану створюють сприятливий фон для подальшого розвитку змагання духовної освіти за власні права на визнання, що ми і бачимо у національному контексті в зв'язку з дискусіями про можливе викладання предмету «Основ християнської етики» у 5-9 класах школи як обов'язкового. Однак, вся аргументація на користь експансії релігійних елементів в освітньому просторі останнім часом виглядає недостатньо продуманою, оскільки забезпечення прав і свобод віруючих чи захист світоглядної нейтральності вочевидь не може приводити до зменшення прав і свобод атеїстів, до сумнівів у об'єктивності наукового світогляду чи визнання МОН релігійного світогляду настільки ж важливим для всієї системи освіти, як і науковий світогляд. Також використання теорії постсекулярного стану як постмодерного подолання новочасового розділення між світським та релігійним входить у суперечність з бажанням українських церков систематично критикувати постмодерний світогляд за його релятивізм та «неомарксиські» «тоталітарні» теорії й практики.

Українські церкви після участі в Євромайдані 2014 року мали значний кредит довіри з боку суспільства і політичної еліти. Саме з цим пов'язане успішне прийняття норм про богослов'я і духовну освіту у законі «Про вищу освіту» та численних підзаконних актах. Також у той переломний період та пізніше церкви відчували обов'язок надати цілісне бачення розвитку України на основі власних богословських концепцій та соціальних доктрин. Однак, такого цілісного бачення так і не було запропоновано. Церкви обмежилися окремими пропозиціями у документах Всеукраїнської ради церков і релігійних організацій, найбільші відомим з яких став документ щодо засад миротворчої діяльності. В цілому склалася парадоксальна ситуація: українські церкви підтримали європейський вектор розвитку України, але не надали бачення специфічності української європейської моделі існування як це бажали зробити за прикладом Польщі та Угорщини, і тому перейшли до критики численних зобов'язань України перед європейськими інституціями, пов'язаними з розширенням розуміння захисту прав і свобод особистості, свободи її самовизначення тощо. 
Опинившись у ситуації полеміки з громадянським суспільством церкви не зайняли послідовної позиції. Наполягання на консервативних цінностях робило українські церкви в очах громадянського суспільства союзниками ідей «русского міра». Власного варіанту українського релігійного консерватизму церкви не запропонували, оскільки відмовилися від розвитку ідей християнської демократії шляхом їх контекстуалізації. Патріарх Святослав на виступі в Києво-Могилянській академії пояснив таку відмову, заявивши, що християнські демократи обов'язково перетворяться на просто демократів, а останні з часом стануть корупціонерами, і тому церкви не можуть підтримувати партійні ідеї та структури, адже відповідальність за політиків може завдати шкоди авторитету церков. Крім того, частим є аргумент, що церкви повинні бути адвокатами всього суспільства, а особливі відносини з християнсько-демократичним рухом можуть цьому завадити. Також на позицію церков впливає специфічно українська ситуація, коли не лише очільники християнських церков, а й лідери ісламу та іудаїзму України представлені у Всеукраїнській раді церков та релігійних організацій, і спільно захищають значимі для них «духовні цінності». За таких умов деяка розмитість уявлень про спільні цінності стає явищем закономірним. А на розмитих уявленнях неможливо формувати цілісний соціальний ідеал, подібний до того, що пропонуються на Заході християнською соціальною доктриною або рухом християнською демократії.

Фактично сьогодні пропозиції українських богословів у області політичної теології є такими, що сприяють розділенню теологів на три табори.

Значна кількість українських богословів притримується ідей західної теології доби постмодерну. Ці богослови виходять з уявлення, що багатовікове протистояння консервативного і ліберального богослов'я, фідеїстичного і раціоналістичного світоглядів, насьогодні стали спадком минулого. Неоконсервативне богослов'я початку XXI століття засновується на визнанні абсолютного значення особистого духовного досвіду для конституювання релігійних теорій - а це було традиційним уявленням для лібералізму. Неоконсерватизм вносить у це уявлення лише надзвичайно важливу поправку: особистий духовний досвід визначається релігійним життєсвітом церковних спільнот. 3 іншого боку, неоліберальне богослов'я визнає, що релігійний світогляд констуйований концептами, які панують у наративах релігійних спільнот. Визнання ролі наративів та спільнот приводить до відмови від ліберального суб'єктивізму, до розуміння закономірного характеру зміни парадигм в історії теології. В результаті трансформацій двох ідейних таборів західної теології можемо констатувати, що неоконсерватизм і неолібералізм збігаються у своєму визнанні провідної ролі інтерсуб'єктивних спіль- 
нот для конституювання релігійного світогляду. Раціоналізм та фідеїзм відійшли у минуле, оскільки в неоконсерватизмі та неолібералізмі пропонуються холістичні теорії теогносії та методології теологічної думки, що враховують лінгвістичний поворот в сучасній філософії та усвідомлення неможливості позбутися впливу тілесного при пізнанні. Бурхливий розвиток теологічних гносеологій під впливом німецької філософської герменевтики та французької феноменології призводить до повного знаття проблеми надмірної спіритуалізації релігійного світогляду та теології. Всередині цього богословського дискурсу відбувається полеміка з питання характеристики власних установок у відношенні до постмодернізму. А саме, одні богослови визнають власну теологію як постмодерну, інші більш помірковано називають свою теологією лише належною до доби постмодерну, треті взагалі вважають теологічні проекти сьогодення такими, що пропонують світогляд «після постмодерну» і тим більше - «після постмодернізму». Таке різноманіття у позиціонуванні викликане як різним баченням характеру відносин між суспільним світоглядом доби постмодерну і християнським світоглядом, так і різним ставленням до того, яка ступінь релятивізму допустима для християнської теології. Разом із тим, навіть більшість тих теологів, що визначають власний світогляд як постмодерний, критично ставляться до релятивізму і намагаються запропонувати новий холістичний світогляд, який би був вільним від штампів мислення доби модерну та був власне альтернативним відносно релятивізму і нігілізму сьогодення.

Друга група українських богословів намагається надати власному світогляду рис неотрадиціоналізму, який би пропонував не лише богословське, а й ідеологічне підгрунтя для захисту християнських цінностей сьогодні. Звичайно такі богослови скочуються до апології різних політичних проектів, серед яких найбільш часто зустрічаємо лібертіанство та популізм як такі, що відповідають церковним проектам постійного оновлення чи то Реформації чи то Традиції. Часом такі богослови починають ставити в приклад Україні політику Трампа чи Обрана. Такі погляди, особливо популярні серед протестантів, власними недоліками мають бажання поєднати у дусі модерну ідеологічне та богословське, утопічне та реалістичне. Те, що для Америки може бути виявом політичного реалізму під впливом Рейнхольда Нібура, в Україні стає чисто утопічним закликом до відкриття потенціалу нової реформації як шляху вирішення всіх соціальних проблем.

Третя група українських богословів намагається спиратися на класичне християнське соціальне вчення у тому його вигляді, якого воно набуло в часи папи Івана Павла II. Відповідні цінності та принципи пропонуються Україні як самодієві, чудотворні засоби для трансформації в бік європейського майбутнього та емансипації творчих сил суспільства. При цьому 
богослови не враховують наявну кризу соціального вчення, яке цілком закономірно сьогодні стало ареною боротьби різних ідейних течій на Заході та пострадянському просторі. Зростання соціальних викликів та неможливість далі посилатися на норми класичного томістичного природного права привела до того, що папи Бенедикт XVI та Франциск природне право повністю звели до високої гідності особистості, розвинули теологію любові як засіб легітимізації соціальної солідарності та як суттєву підтримку правового порядку. Ця соціальна теологія в умовах постмодерну відроджує християнське вчення про світську спільнотність та міжособисте спілкування. Однак, надії на ефективну теологію любові як новий неоавгустіанський період розвитку соціальної доктрини багато у чому залишаються утопічними. Навіть християнські громади не можуть повністю втілювати ідеали спільнотності та міжособистого спілкування у тій його формі, що розвиває соціальне вчення пап Бенедикта XVI та Франциска. Занадто величний етичний ідеал призводить скоріше до того, що християни виявляються беззахисними перед все новими викликами. Все більше богословів Заходу, особливо Німеччини, говорять про необхідність формування католицької концепції реформування суспільства 3 орієнтацією на класичні ідеали соціального вчення як вони були пропоновані папами від Лева XIII до Івана-Павла II. Таким чином, соціальна доктрина стала полем принципових дискусій між прибічниками неотомізму та неоавгустіанства. Перші помірковано оптимістичні у оцінках можливостей людини та намагаються пропонувати реформи капіталізму в бік більшого вияву в ньому рис солідаризму. Другі песимістично оцінюють можливості людини та сучасний глобальний капіталізм, але при цьому $є$ великими оптимістами щодо того, які позитивні трансформації можливі при звільненні соціального потенціалу міжособистого спілкування та спілкування-койнонії. Через солідаризм фактично пропонується новий варіант християнського соціалізму. Принаймні, солідаризм описується як шлях до посткапіталістичних економічних відносин, які оцінюються не лише як більш етичні, більш персоналістичні, а й більш вигідні для пересічних громадян більшості країн.

Таким чином, політична теологія активно розвивається в Україні, частково як самостійний богословський дискурс, частково як продовження соціальної доктрини. Цікаво, що усі три групи українських богословів, що розвивають політичну теологію, бачать сьогодення як особливу епоху переходу до нової якості соціального життя, при якій як значно зростають виклики для особистостей та спільнот, так і з'являються нові можливості для позитивних трансформацій. В цілому механізм формування таких концепцій модернізації чи постмодернізації соціуму стояв у центрі богословських дискусій ще початку XX століття, і релігієзнавча та філософська аналітика з легкістю виявляє елементи утопічних уявлень у таких теорія 
про соціальний перехід до принципово нових якостей соціальних відносин. Сьогодні утопізм богословських пропозицій навіть є меншим, ніж у проектах православних і католицьких богословів початку XX століття.

Антропологічні моделі неоавгустіанства, які лежать в основі нової політичної теології, також визначають особливості сучасної теології освіти. Християнські теорії освіти та виховання були радикально змінені завдяки зусиллям італійських богословів та освітян. Неотомістична теорія виховання початку XX століття була побудована на високій оцінці можливостей звичайного людського розсуду, який шляхом розмірковувань нібито може дійти до метафізичних суджень, які особистістю сприймалися б як самоочевидні. Все чого не може дати застосування такого розсуду може бути отримане завдяки вірі, зокрема - завдяки сприйняттю на віру авторитетних суджень церковної влади. Е. Жільсон, висловлюючись критично щодо такого способу мислення шкільного неотомізму як поєднання примітивних видів раціоналізму та фідеїзму, зазначав, що для тогочасних молодих християн на практиці не були очевидними пропоновані метафізичні роздуми та не відбувалося дійсних проявів релігійної віри при засвоєнні церковних доктрин, що пропонувалися з позицій категоричних суджень авторитету Церкви. Італійський педагог Л. Джусані запропонував радикальну зміну парадигми у методиці прийняття християнського світогляду. Спираючись на Августина і Бергсона, Джусані реабілітує уявлення про широкі можливості інтуїтивного пізнання, але за умови якщо воно виникає і розвивається у межах особистого духовного досвіду. Для томізму вчення про таке пізнання завжди були синонімом платонізму та ідеалістичного спіритуалізму, тоді як сам томізм і неотомізм претендував на реалістичність свого світогляду та своєї гносеології. Джусані посилається на те, що для християн саме досвід духовного народження, досвід живої зустрічі з Богом, досвід особисто-інтуїтивного пізнання є реальністю, яка змінює звичайне життя на християнське. Говорити про нереалістичність особисто-інтуїтивного пізнання значить суперечити християнській та загальнолюдській духовним традиціям. Тому саме вчення про інтуїтивне пізнання має бути основою для християнського реалізму чи хоча б суттєвою частиною цього реалізму. За Джусані, формування духовного досвіду, в межах якого можливі акти інтуїтивного пізнання, є наслідком розвитку культури спілкування і спільнотності. Вважаючи, що церковні громади не надають молоді долучення до цієї культури, Л. Джусані заснував рух «Спілкування та звільнення», що практикує спільнотність за взірцем протестантизму. Це надає значних додаткових можливостей для розкриття потенціалу особистостей на різних етапах їх духовного розвитку - дитинства, молодості, родинного життя. Школи, гімназії, католицькі університети, семінарії мають бути прикладом повного розвитку досконалого міжособистого спілкування і спільнот, щоб постійно зростав 
простір життєсвіту, в якому можливі інтуїції та цілісне інтуїтивне знання себе, інших, світу, Бога, цінностей. Сучасна православна теологія освіти та виховання активно використовує ідеї Л.Джусані, оскільки вони надзвичайно суголосні православній традиції, яка завжди прихильно ставилася до теорій інтуїтивізму та теорій духовного досвіду. Завдяки теоріям сучасної західної теології про інтуїтивне пізнання, що активно сьогодні розвиваються у середовищі католицьких та англіканських мислителів, традиційні православні інтуїтивізм та містико-теологічний емпіризм набувають інтелектуальної респектабельності. Особливо слід відзначити використання православними богословами філософської та теологічної феноменології Ж.-Л. Марйона як постметафізичного інтуїтивізму, філософської та теологічної «постмодерної метафізики» Дж. Мілбанка.

Для всієї теології останнього десятиліття теорії Дж. Мілбанка стали загальним світоглядним підгрунтям для утвердження оптимістичного бачення сьогодення як постсекулярного стану соціуму, що відкриває принципово нові можливості для християнського богослов'я. При цьому теорії Дж. Мілбанка та інших представників очолюваної ним течії радикальної ортодоксії часто критикуються за недоліки їх холістичної гносеології, що наслідує вчення про тотожність знання і віри Гамана. Ця критика є цілком справедливою, оскільки така гносеологія розроблена лише в загальних рисах, $є$ метафізичною за своїм способом конституювання, а тому не може бути переконливою для богословів та філософів. Феноменологічні теорії Ж.-Л.Марйона про інтуїтивне пізнання фактично замінили для сучасних богословів, які в цілому симпатизують світоглядному синтезу Дж. Мілбанка, його гносеологію. Такий вибір є цілком виправданим. Ж.-Л. Марйон надає постметафізичне феноменологічну гносеологію та теогносію, яка враховує розвиток філософських, богословських і релігієзнавчих теорію про богопізнання, що здійснили величезну еволюцію з часів появи робіт М. Шелера «Про вічне в людині», К. Барта «Послання до Римлян», Р.Отто «Священне». Дж. Мілбанк занадто вузько дивиться на проблематику гносеології та теогносії, виходячи 3 традицій кембриджського неоплатонізму контексту для своїх роздумів. Додатковою перевагою феноменологічних гносеології та теогносії Ж.-Л. Марйона $є$ їх відкритість до герменевтики. Богослови активно розвивають власну синтези феноменології та герменевтики, будучи натхненними прикладом П.Рікера. Розвиток сучасної біблеїстики, яка завдяки наратології цілком перейшла на постметафізичну методологію, сприяє успішним синтезам ідей феноменології та герменевтики як для розвитку конфесійних і навіть постконфесійних різновидів філософсько-богословської гносеології та теогносії, так і для суттєвих новацій у методології теології як науки. 


\section{Науково-дослідницький університет як головний ресурс розвитку для теології та духовної освіти}

Слід відзначити, що теологічні новації у православній, протестантській і католицькій теологіях в кінці XX - на початку XXI століть значною мірою можливі через існування богослов'я як академічної дисципліни в університетах Заходу, особливо - США. Участь в університетському академічному дискурсі сприяє формуванню різноманітних богословських шкіл, які відкриті до сучасної науки та філософії. Розвиток діалогічності богослов'я сприяє буму видання богословської літератури на Заході. Сприяють цікавості гуманітарії до теології такі явища як «богословський поворот» у французькій феноменології, використання традиційно релігійних концептів у постмодерній філософії, починаючи з Дерріда. Предметом дискусій стали богословські інтерпретації постсекулярного стану соціуму та суспільного світогляду. Разом із тим, участь в університетському просторі дискусій не завжди сприяє новаторству в теології. У Греції, Румунії, ряді країн Східної Європи православні богословські факультети готують священників і богословів, але в основному там спостерігаємо «теологію повторення». Ця ситуація різко контрастує з прогресивність кількох десятків кафедр православної теології в США та Англії, що на сьогодні стали провідними центрами розвитку богослов'я та діалогу із світським науковим дискурсом, представниками богословської думки католицизму і протестантизму. Велика кількість кафедр богослов'я були відкриті в університетах Росії, але теологія, яка на них представлена, є фактичним перелицюванням релігієзнавства із додаванням семінарської «теології повторення». Основні наукові досягнення православного богослов’я в Росії сьогодні пов'язані з проектами «Православної енциклопедії», Загальноцерковної аспірантури, видавничими проектами з історії православної теології (серії «Візантійська філософія», «Смарагдос філокалія» та інші), із співпрацею богословів та філософів у грантових програмах, координованих сектором філософії релігії Інститут філософії РАН. Також і український досвід доводить, що саме по собі відкриття кафедр богослов'я в різних університетах не приносить помітних плодів на науковій ниві. Найдовше існувала відповідна кафедра в Чернівецькому національному університеті імені Юрія Федьковича, від 1994 року, коли у межах співпраці з УПЦ КП було відкрите богословське відділення і почали здійснюватися спільні навчальні програми університету та Київської православної богословської академії. Також УПЦ КП сприяла розвитку програм з богослов'я та підготовки вчителів християнської етики в Острозькій Академії. Обидва університети активно надавали богословську або релігієзнавчу освіту бажаючим із протестантського середовища. Значну роботу провадила з 2015 року кафедра культурології Національного 
педагогічного університету у межах співпраці з провідними науково-дослідницькими осередками протестантського богослов'я України та Східної Європи. Разом із певними успіхами, в тому числі - у підготовці кадрів вищої кваліфікації, викладачі цих університетів не змогли написати значної кількості наукових досліджень, які б дозволяли говорити, що українське богослов'я вийшло на світовий рівень. Існуючий на сьогодні прогрес в українській теології пов'язаний із функціонуванням науково-дослідницьких інституцій. Багато нових для православного богослов'я ідей було подано у богословських дискусіях та виданнях здійснено невеликим дослідницьким колективом науково-виробничого об'єднання «Дух і літера». Протестантська теологія розвивалася завдяки спеціально створеному наукового колективу Ресурсно-дослідницького центру, який у 2020 році було перетворено на Східно-Європейський інститут теології (Eastern European Institute of Theology). Видані монографії та журнал «Богословські роздуми» стали найбільшим досягненням української протестантської теології, відкрили можливості для інтеграції у світову богословську спільноту. Також найбільші досягнення УКУ пов'язані з функціонуванням у межах цього університету науково-дослідницьких центрів - Інституту історії Церкви, Інституту релігії та суспільства та інших. В цілому, досвід останніх десятиліть доводить, що необхідними для розвитку богослов'я в Україні є науково-дослідницькі університети або науково-дослідницькі академічні інститути, які б задавали б загальний високий рівень інтелектуальної культури для конфесійних систем духовної освіти. Так, УКУ $€$ лідером греко-католицької системи освіти: за цим університетом і його науково-викладацькою спільнотою слідують усі численні семінарії УГКЦ, деякі з яких навіть мають богословські навчальні програми, спільні із УКУ. Спільнота богословів Ресурсно-дослідницького центру (Східно-Європейського інституту теології) не лише створює високу якість наукових досліджень, а й викладає у більшості протестантських семінарій різноманітні курси, які є фундаментально важливими для освітнього процесу. Саме те, що православні України не мають свого єдиного великого наукового центру для забезпечення більших досягнень, які б дозволили богословам ПЦУ або УПЦ адекватно представляти сучасну православну богословську думку в її цілісності в національному контексті. Досвід Роciї, Румунії та Греції показує, що саме по собі існування богословських кафедр чи факультетів не забезпечує прогресу у розвитку теології як науки. Необхідними є саме науково-дослідницькі спільноти, які б могли б завдяки новаторству забезпечувати не просто участь богословів у загальних академічних дискусіях, а й надавали б ідеї, що були цікавими всій гуманітарній науці доби постмодерну. Саме діяльність таких спільнот могла б забезпечувати подальший розвиток духовної освіти в Україні, зміцнити легітимність богослов'я в якості наукової дисципліни. 


\section{Висновки}

Самі богослови та їх симпатики серед дослідників позитивні перспективи розвитку духовної освіти пов'язують із новими можливостями, які нібито надає світогляд постмодерну або пост-постмодерну. А саме, сьогодення оцінюється як постсекулярний стан соціальності, оскільки релігія повертається у публічну сферу. У зв'язку з цим критикується характерний для модерну дуалізм світського і релігійного, модерне ототожнення соціального із світським і віднесення релігійного виключно до приватної сфери. Українські богослови та їх симпатики вважають, що самі по собі криза теорій секуляризації та повернення релігії у публічну сферу легітимізують існування богослов'я як науки та духовної освіти як частини загальнонаціонального освітнього простору. Правове визнання богослов'я у 2014 році відкрило можливості для легітимізації богословських ідей у загальнонауковому дискурсі, але виявилося, що навіть політичне богослов'я та теологія освіти можуть запропонувати лише доволі обмежені проекти, що розвивають ідеї західного постмодерного неоавгустіанства. Ситуація погіршується через панування у значній кількості семінарій та у великій кількості конкретних напрямків богослов'я «теології повторення», через неспроможність запропонувати власні християнсько-демократичні ідеї та створити соціальне вчення, яке б відповідало складним викликам сьогодення. Здійснений аналіз доводить, що сьогодні сталий розвиток мають ті конфесійні системи духовної освіти, які забезпечені лідерськими науково-дослідницькими інституціями, що створюють наукову продукцію високої якості, задають загальний високий рівень викладання і навчання, здійснюють підготовку кадрів вищої кваліфікації. Таким чином, саме модерна технологія створення певної конфесією (чи їх об'єднанням як у випадку протестантів) головного наукового і навчального центру, який діє за всіма національними і світовими стандартами освіти та науки, дозволяє лемітимізувати богослов'я та створити умови для розвитку всіх рядових елементів конфесійних систем духовної освіти.

\section{Посилання:}

Пеннер, П. (2015). Новые горизонты миссии. Черкассы : Коллоквиум.

Пеннер, П. (2019). Новые горизонты миссии 2. Черкассы : Коллоквиум.

Пеннер, П. (1999). Научите все народы... Миссия богословского образования: факторы, определяющие развитие богословского образования в России и странах СНГ. - Санкт-Петербург: Библия для всех.

Санников, С. 2007. Эффективность богословского образования в Украине: исследовательский проект. Одесса: ЕААА.

Соловій, Р. (2012). Виникаюча церква. Черкассы : Коллоквиум. 
Хромець, В. (2019). Богословська освіта в Україні: релігійний і світський контекст. Київ: Дух і літера.

Bohn, D. P. (1997). The Perspectives on Theological Education Evident Among Evangelical Church Leaders in Bulgaria, Hungary, Romania and Russia. Ph.D., Trinity International University.

Charter, M. L. (1997). Theological Education for New Protestant Churches of Russia: Indigenous Judgments on the Appropriateness of Educational Methods and Styles. Ph.D., Trinity Evangelical Divinity School.

Elliott, M. (1999). Recent Research on Evangelical Theological Education in Post-Soviet Societies. Occasional Papers on Religion in Eastern Europe, 19 (1), Article 2, 1-21.

Searle, J. T. (2018). Theology After Christendom: Forming Prophets for a Post-Christian World. Eugene, Oregon: Wipf and Stock.

\section{References:}

Bohn, D. P. (1997). The Perspectives on Theological Education Evident Among Evangelical Church Leaders in Bulgaria, Hungary, Romania and Russia. Ph.D., Trinity International University.

Charter, M. L. (1997). Theological Education for New Protestant Churches of Russia: Indigenous Judgments on the Appropriateness of Educational Methods and Styles. Ph.D., Trinity Evangelical Divinity School.

Elliott, M. (1999). Recent Research on Evangelical Theological Education in Post-Soviet Societies. Occasional Papers on Religion in Eastern Europe, 19 (1), Article 2, 1-21.

Khromets', V. (2019). Theological education in Ukraine: religious and secular context. Kyiv: Dukh i litera. [In Ukrainian].

Penner, P. (2015). New Horizons for Mission. Cherkassy : Kollokvium. [In Russian].

Penner, P. (2019). New Horizons for Mission 2. Cherkassy : Kollokvium. [In Russian].

Penner P. (1999). Teach all nations ... The mission of theological education: factors determining the development of theological education in Russia and the countries of the Commonwealth of Independent States. Saint-Peterburg: Bibliya dlya vsekh. [In Russian].

Sannikov S. (2007). Effective Theological Education in Ukraine: Research Project. Odessa: YEAAA. [In Russian].

Searle, J. T. (2018). Theology After Christendom: Forming Prophets for a Post-Christian World. Eugene, Oregon: Wipf and Stock.

Soloviy, R. (2012). Emerging Church. Cherkassy: Kollokvium. [In Ukrainian].

\section{Yuriy Chornomorets. Prospects for the development of spiritual education in Ukraine}

The article is devoted to a critical study of the vision of Ukrainian theologians of the possible prospects for the development of spiritual education in Ukraine in connection with the general changes expected by various theologians in the position of religion in the national public space, identifying what is really connected with the potential for further positive changes in Ukrainian theology and spiritual education. Ukrainian theologians and their supporters among researchers associate positive prospects for the development of spiritual education with new opportunities that the postmodern or post-postmodern worldview supposedly 
provides. The present is assessed as a post-secular state of sociality, as religion returns to the public sphere. In this regard, the author criticizes the dualism of the secular and the religious characteristic of modernity, the modern identification of the social with the secular, and the attribution of the religious exclusively to the private sphere of life. Ukrainian theologians and their supporters believe that the crisis of secularization theories and the return of religion to the public sphere themselves legitimize the existence of theology as a science and the recognition of spiritual education as part of the national educational space. Legal recognition of theology in 2014 opened up opportunities for the legitimization of theological ideas in general scientific discourse, but it turned out that even political theology and theology of education can only offer rather limited projects that develop the ideas of Western postmodern neo-Augustianism. The situation is aggravated by the dominance in a significant number of seminaries and in a large number of specific branches of theology "theology of repetition", due to the inability to offer their own Christian democratic ideas, due to the refusal to create a social teaching that would meet the complex challenges of our time. The analysis shows that today those confessional systems of spiritual education in Ukraine, which are provided by leading research institutes, have sustainable development. These institutes create high quality scientific products, set the general high level of teaching and learning, and train highly qualified personnel. Thus, it is the modern educational technology of the creation by a certain denomination (or their associations, as in the case of Protestants) of the main scientific and educational center, which acts in accordance with all national and world standards of education and science, that makes it possible to justify theology and create conditions for the development of all ordinary elements of confessional systems of spiritual education.

Key words: theological education, forms of theological education, content of theological education, social vocation of theology.

Юрій Чорноморець - доктор філософських наук, професор, професор кафедри богослов'я та релігієзнавства Національного педагогічного університету імені М.П.Драгоманова.

E-mail: palamist@gmail.com

https://orcid.org/0000-0002-1285-9715

Yuriy Chornomorets - Doctor of philosophical sciences, Professor, Professor of the Department of Theology and Religious Studies of the National Pedagogical Dragomanov University.

E-mail: palamist@gmail.com

https://orcid.org/0000-0002-1285-9715 